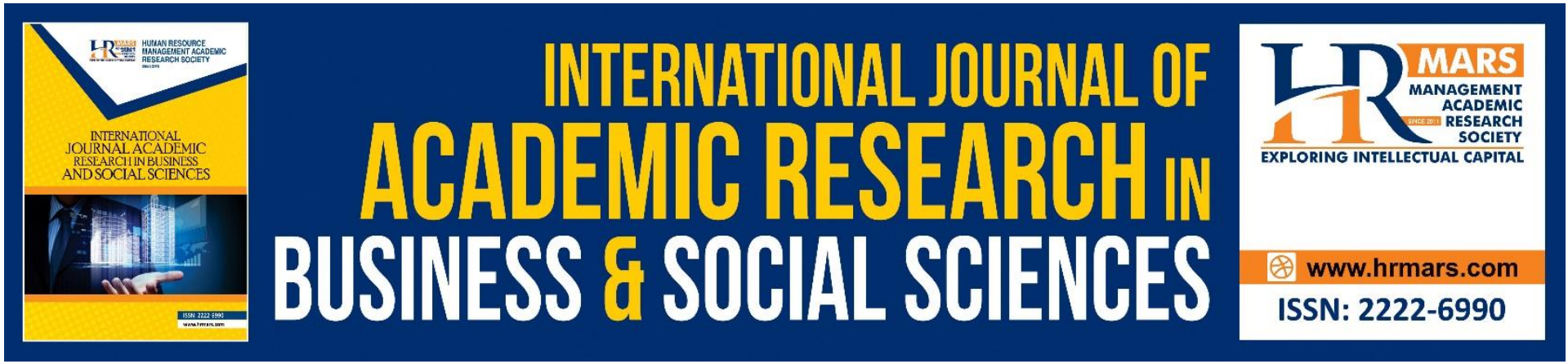

\title{
Argumentation among Qurra' Based on Sanad of Al-Quran
}

\section{Azizul Bin Hassan}

To Link this Article: http://dx.doi.org/10.6007/IJARBSS/v10-i12/8220

DOI:10.6007/IJARBSS/v10-i12/8220

Received: 21 September 2020, Revised: 18 October 2020, Accepted: 17 November 2020

Published Online: 30 November 2020

In-Text Citation: (Hassan, 2020)

To Cite this Article:Hassan, A. Bin. (2020). Argumentation among Qurra' Based on Sanad of Al-Quran. International Journal of Academic Research in Business and Social Sciences, 10(12), 78-90.

Copyright: (c) 2020 The Author(s)

Published by Human Resource Management Academic Research Society (www.hrmars.com)

This article is published under the Creative Commons Attribution (CC BY 4.0) license. Anyone may reproduce, distribute, translate and create derivative works of this article (for both commercial and non-commercial purposes), subject to full attribution to the original publication and authors. The full terms of this license may be seen at: http://creativecommons.org/licences/by/4.0/legalcode

Vol. 10, No. 12, 2020, Pg. 78 - 90

http://hrmars.com/index.php/pages/detail/IJARBSS

JOURNAL HOMEPAGE

Full Terms \& Conditions of access and use can be found at http://hrmars.com/index.php/pages/detail/publication-ethics 


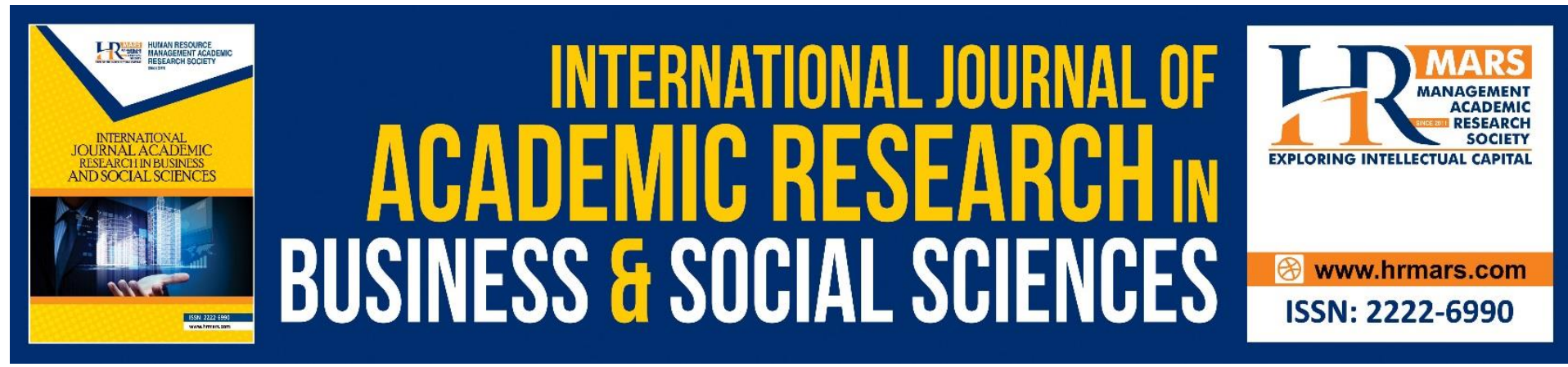

\title{
Argumentation among Qurra' Based on Sanad of Al-Quran
}

\author{
Azizul Bin Hassan, Ph.D \\ Faculty of Islamic Contemporary Studies, Universiti Sultan Zainal Abidin \\ Email: azizulhassan@unisza.edu.my
}

\begin{abstract}
Sanad of al-Quran is a specific award for Muslim community in recitation of al-Quran. It is a high symbolism in Islam when a reciter of al-Quran can become an apprentice to the chain of narrators' lineage for a narration of al-Quran reaching Rasulullah SAW. Meanwhile, Prophet SAW took recitation through talaqqi mushafahah from Jibril AS. The continuity of Quranic sanad from the time of Prophet SAW until present proves that the scholars have hardly strived to spread al-Quran according to methodology of Prophet SAW. Besides that, it is also a tradition regarded as one of the measures in preservation of al-Quran and its authenticity. Recently, the continuity of dissemination of Quranic sanad among Muslim community in Malaysia is seen encouraging. This is in virtue of existence of centres for Quranic studies who take their own initiatives to introduce to the community the Quranic studies with sanad. Positively, it can noourish the practice of Quranic recitation with sanad among the public community. Despite, it still receives criticism especially on the procedure of sanad conferment which is seen as incompatible with its original objective. Therefore, this tiny paper tries to moderate the posed views by discussing on sanad of al-Quran and its argumentation alongside the Qurra' which focused on the procedure of its conferment based on methods of Qurra' mutaqaddimin and mutaakhirrin. Resulting from the survey performed, it was proven that the Qurra' had applied various methods in their teaching and it had academic justification with the objective of preserving the authenticity of sanad and the quality of its holder. Hopefully, it can complement previous writings, elevate clearer understanding on argumentation of Quranic sanad and in turn can educate the community on its importance in Quranic studies.
\end{abstract}

Keywords: Sanad of Al-Quran, Qurra', Argumentation, Authenticity.

\section{Introduction}

Sanad is a specific award for Muslim community in religious learning. al-Suyuti (1984:95) naqal the view of Ibn Hizam in his book "Tadrib al-Rawiyy" that sanad is a specific award by Allah SWT for the people of Prophet SAW and it is not given to other Prophets' people. He supported the statement by bringing upon the view of AbË ÑAi al-Jiyniyy regarding specific award bestowed by Allah SWT to the people of Prophet SAW. It is related to three aspects which are nasab, sanad and I'rab. This becomes a manifestation to the preservation of alQuran by Allah SWT and it truly aligns with His Words: 


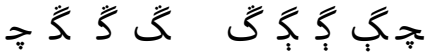

Meaning: "Truly We who descended al-Dzikr (al-Quran) and it is Us who preserve it" (Al-Hijr: 9).

The dissemination of sanad is a pure effort inherited by past Islamic scholars. It is the best method to secure the quality, authenticity and accuracy of a certain Islamic knowledge. The implementation of this system begins with the dissemination of Hadith knowledge. It is performed carefully and scrupulously that a certain narration delivered can be determined of its status from the aspect of narrators and its contents. This phenomenon has formed an effective technique in the process of learning and studying hadith of Prophet SAW. Then, it is able to preserve hadith of Prophet SAW from being fabricated and its propagation can be minimised. Therefore, looking at the effectiveness of this technique, the scholars also implemented it widely to toher disciplines of knowledge such as knowledge of Fiqh (Islamic Jurispridence), Aqidah (Faith) and al-Quran. Then, it began to become a compulsory practice and tradition of the scholars in delivering certain knowledge that its authenticity is secured and blessed as the narration is relied to thiqah scholars or to Prophet SAW.

\section{Issues Related to Sanad}

Quranic studies with sanad have began to gain place among Muslim community in Malaysia. This situation pictures that Quranic teachers have added value to their teaching by endowing sanad to those who are qualified. Generally, the studies are performed either in public institutions such as International Islamic College of Sultan Ismail Petra (KIAS), High Islamic College Johor (MARSAH) and others, and private or personal institutions such as REHAL Resources, Al-Baghdadi Academy and others (Alias \& Mohd, 2015:93; lordanides et al., 2014). Nevertheless, there is no mechanism surveyed specifically and comprehensively on the procedures of sanad conferment and the qualifications evaluated before the conferment. This situation has raised polemic among local scholars who argue the authenticity of sanad and the quality of its holder.

The situation has attracted attention of several Islamic scholars in this field to contribute ideass and information regarding sanad of al-Quran. However, if it is examined closely, the discussed argumentation is not comprehensive until it raises confusion on the procedures of sanad conferment among Quranic teachers. The argumentation poses only several views of a few scholars. In fact, there are several other opinions which should also be explained that this issue can be evaluated justly and balancedly.

Among other issues also brought upon is that, sanad of al-Quran is only eligible to be conferred to only Quranic memoriser group and its conferment to non-Quranic memoriser group is argued. Besides that, there is also a claim that every student who accomplishes his 30-juzuk (part) Quranic memorisation or finishes 30-juzuk Quranic recitation before the teacher, in fact has already gained sanad indirectly from the teacher. This claim has no basis as it should be observed more comprehensively accompanied with rational justification and not just by logic of mind without any concrete academic proving.

Finally, issue regarding the practice of sanad conferment for certain surahs such as surah alFatihah also raises several questions that should be examined in detail based on practice of Qurra'. 


\section{Definition of Sanad}

Sanad (سند) from literal aspect means to climb, lean against and prop up (Ibn Faris: 1990:105:3 \& Al-Jauhariyy, 1990:2:489). From technical aspect, it means the chain of narrators who narrate certain knowledge until it reaches the original source comprising of scholars' writings, hadith or al-Quran. Specifically, sanad alongside Qurra' means a path that connects a qari' to his teacher until Rasulullah SAW in Quranic recitation from aspect of narration and its turuq (Muhammad al-Amin, 2004:149). Hence, it can be understood clearly that sanad of al-Quran obtained must contain the list of its narrators until Rasululullah SAW.

\section{Advantages \& Importance of Sanad}

Sanad is an important component in studies of Islamic knowledge, this has been explained by previous Islamic scholars. Having and seeking of sanad is a sunnah that becomes a practice of those who seek kowledge as stated by Ibn-Mujahid (n.d:49-52) that Quranic recitation is a sunnah obtained by later generation from earlier generation. It is an exclusive award for the people and religion of Islam among Ahlu Sunnah people (Ibn-Taimiah, 1988:7:37). Ibn alJazariyy stated that there is no people who rely on the holy book revealed to their Prophet except Muslim people. Preservation of sanad is really concerned of by the scholars. This can be seen as what happened to Abu Bakar al-Baghdadiyy when he opined that it is permissible to read a of al-Quran by only complying to Rasm of al-Quran and Arabic language without relying on authentic sanad. The statement had caused the scholars in his time to agree of voiding the fatwa and he was punished until he repented and retracted the opinion (AlDhahabiyy, 1997:2:598-600:). Then it can be concluded that sand must be protected by Muslim people that the authenticity of certain knowledge can be maintained, and this is in alignment with the reminder of Imam Ibn al-MubÉrak that the sanad is a part of religious matter, if there is no sanad then anyone will speak of what he wills freely (Muslim, n.d:1:15).

\section{History of Quranic Sanad}

In fact, preservation of Quranic sanad is not a new subject. It did begin since the time of revelation upon Prophet SAW. Among the evidence referring to the matter is the expression "...by intermediary of Jibril AS..." in definition of al-Quran (Rosmawati, 2010:25). Obviously, it relates the reception of al-Quran by Prophet SAW from Jibril AS. Then, relation of sanad was also mentioned by the Companions RA who received certain recitation directly from Prophet SAW. This can be observed by athÉr Sahabat narrated by Ubay Bin Ka'ab: "Prophet SAW

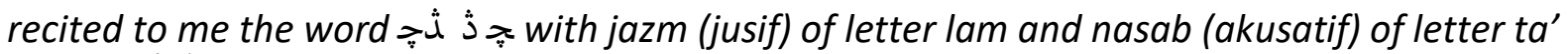
(وَلَّيَقُولُوا دَرَسْتَ)" (Al-Hakim, 1986:2:260). That also happened in an athÉr recorded regarding dispute between Umar al-Khattab RA and Hisham RA on the contradiction of recitation that they received from Prophet SAW (Al-Bukhariyy, 2001:3:122). As a conclusion, the scholars have made istinbat of law to the situation through two aspects which are regarding the authenticity of reliance of Qiraat to Prophet SAW and the question on the narrators of the recitation (Al-Matiriyy, 2013:58). This subject was continued by the scholars until late first century through delivery, conferment and proving of sanad which were only performed verbally. In early second century, the scholars began to pay serious attention to the chains of sanad received in their time in written. If it is examined, the Qurra' had preserved those sanads by the following means: 


\section{- Listing of sanad in the introduction of book}

The tradition that becomes a practice and inheritance of the Qurra' is by stating the sanads obtained from their teachers. The objective is that each reader who studies the book can recognise clearly the lineage of sanad narrators of its author, therefore further studies to each narrator and the flow of sanad can be performed (Al-Sakhawiyy, 2002:8). It is a very concrete proving to the obtainment of sanad as it was written on paper sheets. Among the examples are the listings of sanad by Qurra' as follows:

- Imam Ibn-Mujahid (t.t:88-101) in the book al-SabÑah under topic:

$$
\text { "ذكر الأسانيد التي نقلت إلينا القراءة عن أئمة أهل كل مصر من هذه الأمصار" }
$$

- Imam Makkiyy Bin Abu Talib (1969:196-214) in his book al-Tablirah under topic:

$$
\text { "ذكر اتصال قراءتي بهؤلاء الأئمة السبعة الذين قدمت ذكرهم." }
$$

- Imam al-Sakhawiyy (2002:8-33) in his work Fath al-Wasid listed sanad of his teacher Imam al-Shatibiyy under topic:

$$
\text { "ذكر نبذ من فضائل أبي القاسم ومولده ووفاته وشيوخه." }
$$

- Imam Abu Amr al-Daniyy (2006:10-16) in his work al-TaisÊr under topic:

$$
\text { “الإسناد الذي أدى إلى القراءة عن هؤلاء من الطرق المرسومة عنهم رواية وتلاوة" }
$$

- Syeikh Mahmud Bin Abdul Khalid Jaddi (1992:27-42) during tahkik of the work Ibraz alMa'aniy authored by Imam Abu Shamah also listed his sanad in the introduction of the book in the topic:

$$
\text { “الإسناد الذي أدى إلى قراءات الأئمة السبعة من الطرق المرسومة عنهم رواية وتلاوة.” }
$$

\section{- Writing of specific books regarding sanad of al-Quran}

Considering the large importance of sanad, the scholars had improvised their writing methodology by listing and elaborating in specific the sanads that they obtained in specific writing regarding the sanad only. It is a reference and guideline for later generations to the sanads that reach in their time that they will be preserved. Among the examples are:

- Writing of Ibn al-Bazhish (1982:1:123) titled "Al-Turuq Al-Mutadawilah Fi Al-Qiraat". He clearly tried to list all sanads obtained in the book but it was not completed before his decease.

- Imam Ibn-Sallar (2002:18-44) in his work "Tabaqat Al-Qurra' Al-Sab'ah Wa Dzikr Manaqibihim Wa Qiraatihim".

- Imam Ibn al-Jazariyy (2014) in his work titled "Jami' Asanid Ibn Al-Jazariyy" also mentioned his sanads in the book.

\section{- Listing of sanad on ijazah of al-Quran}

ljazah of al-Quran is a pledge of permission given by a teacher to his student in narration of Quranic recitation. It is different with sanad as the names of narrators are not written on it but it is adequate with the teacher's approval to eligibility of his student. As the conferment of ijazah is a recognition to the student then, for the teacher with sanad they will elaborate in the ijazah all narrators for a certain narration (Al-Matiriyy, 2013:73). Despite, there are Quranic teachers who provide ijazah to their students but do not list the sanad as he does not have it. This happened to the writer who had talaqqi of al-Quran according to Riwayat Hafs 'an Asim Tariq al-Shatibiyyah with Syeikh Bassam al-Nutshah under organisation of Jam'iyyah Muahafazah ‘ala al-Quran al-Karim, Mafraq, Jordan in year 2006. 
Based on the matters, it explains that listing of sanad narrators' name in written form is obligated. This is due to the following reasons:

- The details of sanad can be determined from aspect of strength and weakness of its chain, status of Qiraat either it is mutawÉtirah or shÉzh, and can recognise the accuracy of narration through written sanad conferred by the teacher (Al-Daniyy, 2011:1:246:).

- Listing of sanad also can differentiate the position of sanad whether it is high (Aliyy) or low (Nazil). Imam Ahmad Bin Hanbal stated that seeking of a high sanad (Aliyy) was a sunnah of past generations (Ibn al-Salah, n.d:1:160). Furthermore, it also put someone close to Prophet SAW or Allah SWT (Al-Tisiyy, 2004:280). The status of sanad is classified by Imam al-BaiqËniyy (1999:1:9) as the following expression:

-

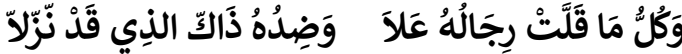

Meaning: "And everything few in number of narrators then is regarded as high ...And the one in opposite is regarded as low".

- The listing also can recognise the details of narrator from aspect of al-liabï, al-ÊtqÉn and the method implemented in sanad conferment (Al-Jazariyy, t.t:1:30).

If it is not written then definitely it will open a space to anybody with a claim of having read al-Quran with certain teachers and directly receiving sanad from the teacher. In fact, sanad is the highest recognition of a teacher to his student, not all who read al-Quran before him will be conferred sanad. This statement is supported by dictation of Ibn al-Jazariyy (t.t:2:58) about Syeikh Muhammad Badhan al-Dimashqiyy who conferred ijazah of Quranic narration to only two students out of all students who read before him which were Al-Saif Al-Haririyy and Ibn Nahlah. Besides that also, not all Quranic teachers have sanad of al-Quran.

Then, looking at those situations, every person who claims of having sanad must prove it in written form. Failure of performing that will cause the claim of having sanad verbally to be difficult of acceptance as there is no written proof except that he can explain the list of sanad narrators completely and the authenticity of the sanad is approved by authorised individual. This is as a person who claims that he has studied in a university but fails to prove the university's recognition in written form. Then definitely, the claim will be rejected and disbelieved. It also complies with Usul Fiqh method "ما لا يتم الواجب إلا به فهو واجب which is "Anything that cannot fulfill obligatory matter except with it then, the subject is also obligatory of seeking".

Hence, it can be concluded that there are several categories of Quranic teachers which are:

- يجيز ويسند: Teacher who confers ijazah to his student with sanad.

- يجيز ولا يسند : يجند : Teacher who confers only ijazah to his student with without sanad.

- يسند ولا يجيز: Teachers who only confers sanad to his student without ijazah.

- لا يجيز ولايسند: Teacher who does not confer sanad and ijazah to his student.

\section{Method of Sanad Conferment}

To ensure that the heritage of Islamic knowledge is delivered to the next generation properly and completely, then the Qurra' have put their maximal effort to ensure that the method implemented is based on the genuine manhaj nubuwwah. However due to the revolving time 
and several factors, then there are a few method of sanad conferment that become a discussion among Islamic scholars. To explain the situation, then it must be looked the methods used by the Qurra' generally which are:

\section{i- Al-Sima' (السماع)}

This method is an adaptation from method of Prophet SAW. This refers to the reprimand to Prophet SAW by Allah SWT during revelation. As Prophet SAW felt worried of forgetting something from the revelation delivered then Prophet SAW had moved his tongue aiming to repeat the verse of al-Quran before the revelation was completely read to Prophet SAW. Thus, looking at the haste done then Allah SWT directly remind Prophet to "listen" carefully in advance the recitation delivered by Jibril AS before repeating it. This situation is recorded in al-Quran in Surah Taha: 114 and Al-Qiyamah:16.

\section{ii- Al-'Aradh (العرض)}

There are many athar of Companions RA regarding this matter. Among the famous ones is the narration of Abdullah Bin Abbass RA clearly stating that Prophet SAW presented His recitation before Jibril AS at every night in the month of Ramadhan (Al-Bukhariyy, 2001:538). This process combines several important elements emphasising on aspect of memorisation, recitation, interpretation and comprehension of explicit and implicit meaning (Al-Dakhil, 2008:46).

Therefore, narration of al-Quran is obligated of containing one or both of those methods. It becomes a general pre-requisite before a student can continue his learning and narrate his teacher's recitation with sanad. There are several specific methods practised by the Qurra' in sanad conferment, specifically as follows:

1. Obligation of 30-Juzuk Quranic memorisation and several matan of Tajwid such as Tuhfah al-atfal, Muqaddimah al-Jazariyyah and others:

This method is a continuity of Qurra' Mutaqaddimin's practice who wanted to produce quality in every holder of Quranic sanad. This is because they opined that all narrators of sanad are memorisers of al-Quran, while addition of memorisation to several basic matan of tajwid is an added value that the student's ability aligns with the theoretical and practical aspect (Usamah, 2005:134-136). Hence, for the masyaikh who hold to this method, they do not confer ijazah or sanad to those who do not fulfill the posed conditions. However, sanad which is regarded as an exclusive right of Muslim people is not able to become a strong reliance as it is more specific to only Quranic memorisers, in fact accurate Quranic knowledge must be disseminated to all groups. Meanwhile, regarding the narrators of al-Quran who comprise of Quranic memoriser group, it is because of advantage and specialty for the past generation in memorising al-Quran.

2. It is obligatory to memorise 30-juzuk al-Quran, but if he has learnt and performed talaqqi with other teacher previously then a test is done to test the skillfulness of the Qari. If the Qari is admitted of his excellence, then he is eligible of sanad conferment by reciting only a part of al-Quran: 
This method is practised widely by Qurra' Mutaqaddimin and Mutaakhirin, this situation frequently occured to famous Qurra' who wanted to get chance of getting his recognition or to improve sanad position to a higher status, therefore many students perform talaqqi by this method. Among the examples that can be witnessed are:

a. Imam Ibn al-Jazariyy (t.t:1:180) got his chance to have talaqqi of twelve Qiraat with his teacher Abu Bakar Bin Abdullah al-Jundiyy until words of Allah SWT:

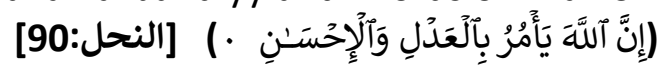

Then his teacher fell sick, then before his decease, Ibn al-Jazariyy requested that he was given ijazah of the Qiraat recitation.

b. Imam Ibn al-Jazariyy (t.t:1:33) received ijazah of al-Quran from his teacher Imam Ahmad Bin Ibrahim al-Tahhan by reciting only a rubu' of al-Quran according to riwayat Ibn 'Amir and al-Kisaiyy, then reciting surah al-Fatihah and beginning of Surah al-Baqarah according to ten Qiraat as jama'.

c. Ridwan Bin Muhammad al-'uqubiyy (Al-Barmawiyy, 2000:2:120) was conferred sanad from Imam Ibn al-Jazariyy by reciting only surah al-Fatihah and beginning of Surah al-Baqarah as jama' of ten Qiraat.

d. Abu al-Qasim Muhammad Bin Muhammad al-Nuwairiyy (Al-Barmawiyy, 2000:2:349) recited some parts of al-Quran according to narration from Tariq al-Tayyibah, then Imam Ibn al-Jazariyy conferred ijazah for other parts.

e. Syeikh Bakri Abdul Majid al-Tarabishiyy (Al-Warraqiyy, t.t:85) took recitation of Riwayat Hafs with mode of Qasr al-Munfasil and Tawassut al-Munfasil from his teacher Syeikh Hussin Khitab. Meanwhile Syeikh Hussin Khitab took the recitation from Syeikh Abdul Qadir Quwaidir al-Arabailiyy who took recitation from Syeikh Ali Muhammad al-Dabba.

However, it should be concerned that, this method is not an easy practice to be performed. The Qurra put several conditions that need to be obeyed before conferment of ijazah through this method. Among the agreed conditions alongside the Qurra' are:

- Al-Itqan: Competence is an important element for a student that needs to be proven to qualify him of getting ijazah and sanad from famous Qurra' and a high sanad. It definitely will not be achieved in short duration except that the student has performed talaqqi and mastered Qiraat discipline with several other teachers previously. Therefore, ijazah and sanad will not be conferred if there is no experience of talaqqi in previous. However, there was also among Qurra' who conferred ijazah of recitation to his student who had never attended talaqqi with anybody previously. It was practised by Syeikh Salih Ahmad Bin Muhammad alIdrisiyy al-Arkaniyy al-Rabighiyy (Ahmad, 2002:1:94).

- Al-Taqwa: Taqwa (piousness) is a spiritual element that is always attached so that every ijazah and sanad recipient will be honest with what they obtain and do not use them for worldly purpose. Hence, every ijazah conferred through this method will be written on it the expression:

$$
\text { “ قَرَاً عَلَيَّ بَعْضَ القُرآنِ وَأَجَازَهُ بِالبَاقِي.. }
$$


3. Recitation through memory is not obligated but it is adequate to recite by reading the mushaf only:

This method is practised widely by Qurra' Mutaakhirin, as of a high consciousness among public community to get sanad Quranic recitation even though they are not able to memorise al-Quran. Moreover, some Qurra' opine that Quranic knowledge must be spread widely to all Muslim community in every level. This view was supported by Imam al-Suyutiyy (1974:1:344) in his book al-ItqÉn in the chapter (كيفية تحمله) by mentioning:

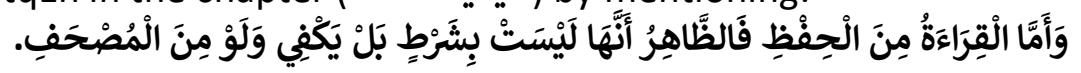

Meaning: "...And truly recitation (of al-Quran) is through memorisation, but explicitly it is not an obligatory condition. Indeed the recitation is adequate just by reading mushaf...".

Besides that, several hadith of Prophet SAW also in general do not specify sanad to only Quranic memoriser group as understood through the words of Prophet SAW:

$$
\text { خَيْرُكُمْمْ مَنْ تَعَلَّمَ الْقُرَآنَ وَعَلَّمَهُ }
$$

Meaning: "The best of you are those who learn al-Quran and teach it" (Al-Bukhariyy, 2001:6:192) (Hadith No:5027).

That also goes to His SAW's saying:

$$
\text { مَنْ يُرِدِ اللهُ بِهِ خَيَرًا يُفَقِّهُ فِي الدِّينِ }
$$

Meaning: "Whoever intended by Allah SWT a goodness, then he will be bestowed with good understanding in religion". (Al-Bukhariyy, 2001:1:25) (Hadith No:71).

If examined, in the first hadith of Prophet SAW, He did not use the word "حَفِظَ" which means

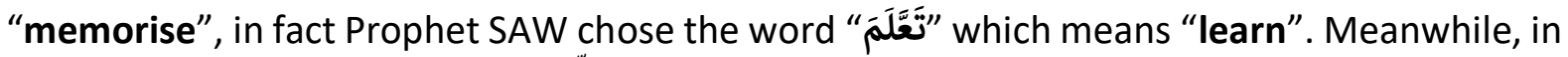
the second hadith, the word "يُفَقِّهُ" is used a proof that the aspect of concern is firm understanding of the learnt knowledge and not just by mere memorisation. Hence, denying this method in absolute in sanad conferment is not relevant, this is because the Qurra' do not merely confer ijazah through this method but in fact put a quite strict condition like al-Itqan theoretically and practically. Besides that, it is also stated in ijazah and sanad the expression "قَرَاً عَلَيَّ حَاضِرِارانُظرًا مِنَ المُصْحَفِ as an explanation that the student takes recitation by reading mushaf.

Therefore, the statement relating a recitation taken by reading mushaf can decrease the quality of sanad is irrelevant, this is because not all who memorise al-Quran have accurate recitation but in fact there are some who do not memorise al-Quran but are very skillful and good in the recitation.

4. The recitation is divided into several parts (tajziah), every part is recited with different narration

This method is applied by many Qurra' by allowing the students to perform talaqqi as tajziah which is by dividing the recitation into several parts with different Qiraat. For example, student recites the first hizb with Riwayat Qalun, then the second hizb with Riwayat Warsh and next hizbs with other riwayats as sequence or narrators until complete either with seven or ten Qiraat. Among the Qurra' who implemented this method are as follows: 
a. Syeikh Zakaria Abdul Salam Al-Jamajumuniyy performed talaqqi of al-Qiraat al-Asyr alKubra with Syeikh Abu Lailah al-Fadiliyy as tajziah. He also implemented the method to his students by obligating the students to bring upon evidences from Shatibiyyah, Durrah and Tayyibah for each riwayat recited (Al-Warraqiyy:t.t).

b. Syeikh Dr Ali Muhammad Taufiq al-Nuhhas performed talaqqi with his teacher Syeikh Abdul Razzaq al-Bakriyy with recitation as tajziah, and Dr Hussin al-Warraqiyy received recitation from Syeikh al-Nuhhas through the same method (al-Warraqiyy:t.t).

c. Syeikh Sayyid Lashin performed talaqqi with Syeikh Abdul Fattah al-Qadiyy on the Ten Qiraat through tajziah (Al-Barmawiyy, 2002:1:112).

Nevertheless, there are also among the Qurra' who disagree with this method as it does not comply with the method used by Mutaqaddimin generation such as Syeikh Kuraim RÉjil and others.

\section{Reading khilaf Qiraat only}

This method obligates the student to finish Quranic recitation according to Riwayat Hafs in advance before reciting the next riwayat. Then the student will be taught on the method of usul Qiraat for the next riwayat and the student only recites the verses where there is khilaf in it from beginning to the end. This method is repeated for each riwayat learnt and it is excepted for Riwayat Warsh and Qiraat Hamzah as the khilaf in it is vast. This is a combination of Mutaqaddimin method who practised recitation method as ifrad which is by obligating the student to recite each riwayat from the beginning to the end without mixing with other riwayat. This is as recorded on the manner of talaqqi by Syeikh Ali Bin Shuja al-Abbasiyy who performed talaqqi with Imam al-Shatibiyy by reciting each Qiraat with three times khatam. For example recitation of Qiraat Ibn Kathir, the first recitation with Riwayat Qanbul, the second recitation with Riwayat al-Bazziyy and the third recitation is a combination of both riwayat (al-Jazariyy:T.t:1:326). Meanwhile Qurra' Mutakhirrin pioneered by Imam Ibn alJazariyy recited as jama' which is by gathering all khilaf contained in each verse either according to seven or ten Qiraat.

Explicitly, many opine that recitation of ayat khilaf is a less suitable method as it is too easy and lenient. But if it is compared with recitation as jama' then this method is seen more suitable and more beneficial. Among the benefits gained are:

a. The student will be exposed to usul and farsh huruf of each narration for all Qiraat and practise it to the verses containing khilaf perfectly.

b. Every student will repeat the recitation for 14 times for Qiraat seven, 20 times for Qiraat Ten compared to recitation as jama' which recites all khilaf in only a round of khatam.

c. The student will understand clearly the manhaj of each riwayat and can differentiate manhaj of all Qiraat well.

d. The student is also able to recognise luruq for each riwayat well and then avoid mixture or talfiq riwayat.

e. It is a key to recitation as jama' that needs ability of the student to separate narrations in a recitation. 


\section{Sanad al-Musalsalat}

It refers to an agreement of the narrators of a certain hadith on the specific method in the delivery of the hadith either in verbal or action or both forms (Al-Tanjiyy, 2002:5). Generally, narration of hadith is allowed only through listening of its pronouncement from the teacher (Al-Mazruiy, 2009:270). However, for narration of al-Quran most of the Qurra' do not allow this method to be performed as al-Quran needs practical aspect of a good recitation. This method is also named as "Al-ljazah Min Ghairi Qiraah" (Al-Mazruiyy, 2003:42). When examined closely, there are several Hadith Musalsal related to certain surahs in al-Quran. It is listed in the book al-Ujalah Fi al-Ahadith al-Musalsalah authored by Imam Al-Fadaniyy as follows:

a. Al-Musalsal Bi Qiraah Surah al-Fatihah (1985:1:119).

b. Al-Musalsal Bi Qiraah Surah al-Saf (1985:1:22).

c. Al-Musalsal Bi al-Sujud Fi al-Insyhiqaq (1985:1:23).

d. Al-Musalsal Bi Qiraah Surah al-Kauthar (1985:1:25).

e. Al-Musalsal Bi Qiraah Ayat al-Kursiyy (1985:1:24).

f. Al-Musalsal Bi Qiraah Surah Al-Asr (1985:1:25).

According to Dr Tawfiq Dhamrah (Temubual: 2015) related to those hadith, he concluded as follows:

- It is not allowed for anybody to confer sanad for certain surahs in al-Quran except for riwayat musalsal stated as above.

- It is not allowed for Quranic teachers to cofer ijazah of surah recitation from those hadith before taking the hadith's narration from the teacher who owns it.

- It is not allowed to use sanad of Riwayat Hafs recitation while conferring sanad musalsal except after listening to the hadith in advance from a teacher with sanad.

- It is adequate that a sanad is conferred to a student just by listening to teacher's recitation as it is exemplified as hadith. However, it cannot be a proof of a person's accurate recitation from tajwid aspect. It is only valid from aspect of narrative method and not practical recitation.

Thus, it is not necessary for someone to view this type of narration as a fault. This is because its narration relies on method of hadith narration which is approved of its permissibility.

\section{Conclusion}

Narration of al-Quran through Talaqqi Mushafahah method is an obligatory method that should be implemented. The event where Prophet SAW performed talaqqi of al-Quran with Jibril AS is an undeniable proof. Therefore, there is no perfect method in Quranic learning other than the method. This is because each reciter can rely his recitation to his teacher until reaching Prophet SAW.

Past scholars had put their best effort in securing that the recitation received is authentic through sanad that arrives to them. Hence, various methods and techniques had been developed by them to ensure that Quranic knowledge is spread and preserved. Thus, we should look at this continuity procedure of sanad knowledge from the side of Qurra' Mutaqaddimin and Mutaakhirin that there would be no confusion leading to accusation of no basis. 
Based on all methods implemented by Qurra' Mutaqaddimin and Mutaakhirrin hence, it is necessary that every Quranic reciter to be open-minded with the applied methods. It is possible that some of the methods are not agreed by some Qurra' but, in fact the practice was practised by some other Qurra' whose knowledge and status were approved.

It is unnecessary for us to blame the method used just because we hold to one of the methods widely practised among the Qurra'. This is because, all Qurra' had concrete justification to perform that.

Therefore, the most important thing is to be moderate with the practised view. This is because the focus is still one which is to spread Quranic knowledge among the community especially regarding sanad. If it still becomes an exclusive right for only certain groups in Islam, then knowledge of Quranic sanad will only revolve around the groups and public community who have interest will have no chance of deepening knowledge in it as memorisers of Al-Quran. It is also worried that the spread of Quranic knowledge will be difficult to develop if this condition does not accept any change based on the revolving time for the sake of global Muslim community.

Hopefully we all can become the successors of a good Quranic generation by avoiding any occurence of clash that will waste the community. Mutual respect is an attitude that must be practised in celebrating the diversity of opinions and it is more compatible with the title as "Ahlul Quran".

\section{References}

Ibn-Taimiah. (1419H/1988). Minhaj Al-Sunnah Al-Nabawiyyah. Maktabah Ibn Taimiah.

Al-Amin, M. S. M. (2004). Al-Isnad Inda Ulama al-Qiraat. Arab Saudi: Al-Jami'ah Al-Islamiyyah Bi Al-Madinah Al- Munawwarah.

Al-Baiquniyy, M. U. (1999). Al-Manzumah Al- Baiquniyyah. Dar Al-Mughniyy Linnashr Wa AlTauzí .

Al-Barmawiyy, A. I. (2000). Imtá Al-Fudala' Bitarajim Al-Qurra' Fima Ba'da Al-Qarn AlThamin Al- Hijriyy. Dar Al-Nadwah Al-Alamiyyah.

Al-Badzish, A. A. (1982). Al-Iqna' Fi Al-Qiraat Al-Sab’ . Jamiah Umm Al-Qura: Markaz Al-Bahth Al-Ilmi Wa Ihya Al-Turath Al-Islamiyy.

Al-Bukhariyy, I. M. (2001). Sahih Al-Bukhariyy. Dar Tauq Al-Najah.

Al-Dakhil, A. D. (2008). Iqra' Al-Quran Al-Karim: Manhajuhu Wa Shurutuhu Wa Asalibuhu Wa Adubuhu. Jeddah: Markaz Al-Dirasat Wa Al-Malumat Al-Qur'aniyyah, Maahad Imam Al-Shatibiyy.

Al-Daniyy, S. (1427H/2006). Al-Taisir Fi Al-Qiraat Al-Sab': Tanta: Dar Al-Sahabah Litturath.

Al-Daniyy, S. (1433H/2012). Jamí Al-Bayan Fi Al-Qiraat Al-Sab' Al-Mashhurah. Tanta: Dar AlSahabah Litturath

Al-Dzahabiyy, A. (1417H/1997). Marifah Al-Qurra' Al-Kibar ‘Ala Tabaqat Wa Al-Asar. Beirut: Dar Al-Kutub Al-IImiyyah.

Al-Fadaniyy, I. (1985). Al-Ujalah Fi Al-Ahadith Al-Musalsalah. Dimashq: Dar Al- Basair.

Al-Jazariyy, Y. (1435H/2014). Jamí Asanid Ibn Al-Jazariyy. Arab Saudi: Maktabah Al- Jamiah Al-Islamiyyah Bi Al-Madinah Al-Munawwarah.

Al-Matriy, S. A. (1434H/2013). Asanid Al-Qiraat Wa Manhaj Al-Qurra' Fi Dirasatiha: Dirasah Nazariyyah Tatbiqiyyah. Arab Saudi: Kursiyy Malik Abdullah Bin Abdul Aziz Lilqur'an AlKarim. 
Al-Maqdisiyy, S. A. (1413H/1992). Ibraz Al-Maaniyy Min Hirz Al-Maaniyy. Arab Saudi: AlJamiaah Al-Islamiyyah Bi Al-Madinah Al-Munawwarah.

Al-Mazruiyy, I. Y. (1424H/2013). Al-Tibyan Liman Talab ljazah Al-Qur'an. Kuwait: Maktabah Al-Manar Al-Islamiyyah.

Al-Mazruiyy, I. Y. (1430H/2009). Audah Al-Dilalat Fi Asnid Al-Qiraat. 14

Al-Qasimiyy, J. M. (1425H/2004). Qawaid Al-Tahdith Min Funun Mustalah Al-Hadith. Muassasah Al-Risalah.

Al-Sakhawiyy, A. (1423H/2002). Fath Al-Wasid Fi Sharh Al-Qasid. Riyad: Maktabah Al-Rushd.

Al-Suyutiyy, J. (1394H/1974). Al-Itqan Fi Ulum Al-Qur'an. Al-Hai'at Al-Misriyyah Al-Ammah Lilkitab.

Al-Suyutiyy, A. (n.d). Tadrib al-Rawiy Fi Sharh Taqrib Al-Nawawiyy. Dar al-Tayyibah.

Al-Tanjiyy, A. B. F. A. (1423H/2002). Majmú Musalsalat Fi Al-Hadith. Beirut: Dar Al-Kutub AlIlmiyyah.

Al-Waraaqiyy, A. H. M. (n.d). Tuhfah Al-Ikhwan Bima Ala Min Asanid Hadza Al-Zaman. AlQahirah: Muassasah Qurïubah.

Mokhtar, W. K. A. W., Khairuldin, W. M. K. F. W., Ibrahim, A., \& Embong, A. H. (2018). Al'Aqīdaț Al-Ṣahịhaț as the Essential Element of Worldview of Development Integrity and Accountability. International Journal Of Academic Research In Business And Social Sciences, 8(11), 328-337.

Ridzuan, F. N. B., Mokhtar, W. K. A. W., Afifah, A., Amiruddin, R. E., \& Jamaludin, A. S. (2019). The Characteristic And Issues In Liberal Islam In Malaysia. International Journal Of Academic Research In Business And Social Sciences, 9(11).

Hamid, N. C., \& Mokhtar, W. K. A. W. (2019). The Comprehensive Aspect In Islam From Quran And Hadith Perspective. International Journal Of Academic Research In Business And Social Sciences, 9(11).

Hamid, N. C., \& Mokhtar, W. K. A. W. (2019). The Comprehensive Aspect in Islam from Quran and Hadith Perspective. International Journal Of Academic Research In Business And Social Sciences, 9(11).

Iordanides, G. D., Bakas, T., Saiti, A. C., \& Ifanti, A. A. (2014). Primary Teachers' and Principals' Attitudes towards Conflict Phenomenon in Schools in Greece. Multilingual Academic Journal of Education and Social Sciences, 2(2), 30-52.

Nafi, N. M., Mokhtar, W. K. A. W., \& Mustaffami, M. (2019). The Holy Quran Memorization In Globalization Era. International Journal Of Academic Research In Business And Social Sciences, 9(11). 